\title{
MI M2 macrophage expression in menstrual blood flakes of women with endometriosis
}

\author{
Yulisa Haslinda', Ashon Sa'adi', Hendy Hendarto', Faroek Hoesin ${ }^{2}$ \\ 'Department of Obstetrics and Gynecology, ${ }^{2}$ Department of Anatomic Pathology \\ Faculty of Medicine, Universitas Airlangga, Dr Soetomo Hospital, Surabaya
}

\section{ABSTRAK}

Tujuan: Mengetahui dan membuktikan peningkatan ekspresi panmakrofag, makrofag M1, dan makrofag M2 serta penurunan rasio M1/M2 pada serpihan darah menstruasi wanita endometriosis.

Bahan dan Metode: Penelitian ini bersifat analitik observasional cross sectional pada 30 subyek penelitian endometriosis dan non endometriosis. Dilakukan pewarnaan imunohistokimia pada sampel darah menstruasi dari subyek penelitian yang diambil pada hari kedua atau ketiga dengan antibodi CD68 dan CD163 untuk mengukur ekspresi panmakrofag dan makrofag M2. Ekspresi makrofag M1 merupakan pendekatan dari pengurangan ekspresi panmakrofag $\mathrm{M} \varphi$ dengan makrofag M2.

Hasil: Ekspresi M1, M2 dan rasio M1/M2 pada kedua kelompok penelitian memiliki distribusi normal kemudian dilanjutkan uji independent t-test dengan $\alpha$ one tailed 0,05 . Probabilitas dianggap bermakna secara statistik bila nilai $\mathrm{p}<0,05$ dengan selang kepercayaan 95\%. Berdasarkan hasil statistik didapatkan ekspresi makrofag $\mathrm{M} \varphi$, pada kelompok endometriosis dan kontrol sebesar 3,62 $\pm 0,50$ dan 2,80 $\pm 0,64$ dengan hasil uji beda non parametrik didapatkan $\mathrm{p}=0,0005$. Rerata ekspresi makrofag M1 pada kelompok endometriosis dan kontrol masing-masing $1,40 \pm 0,35$ dan $1,33 \pm 0,40$ dengan hasil $\mathrm{p}=0,3005$. Rerata ekspresi M2 pada kelompok endometriosis dan kontrol sebesar 2,23 $\pm 0,41$ dan 1,47 $\pm 0,36$ dengan hasil $\mathrm{p}=0,0005$. Rasio M1/M2 pada kelompok endometriosis dan kontrol sebesar $0,65 \pm 0,20$ dan 0,92 $\pm 0,24$ dengan hasil $\mathrm{p}=0,0015$.

Simpulan: Terdapat peningkatan bermakna pada ekspresi panmakrofag $\mathrm{M} \varphi$, makrofag $\mathrm{M}$, serpihan darah menstruasi wanita endometriosis dan terdapat penurunan bermakna pada rasio M1/M2 serpihan darah menstruasi wanita endometriosis.

Kata kunci: darah menstruasi, endometriosis, imunohistokimia, makrofag M1, M2

\begin{abstract}
Objectives: to measure and prove the increase of panmacrophage, macrophages M1 and M2 expression and decrease of ratio of M1/M2 in menstrual blood flakes of women with endometriosis. Materials and Methods: This study was a cross sectional observational analytic study conducted on 30 subjects with endometriosis and non-endometriosis. Immunohistochemical staining was done on a sample of menstrual blood flakes of subjects study who were taken at the second or third day of menstrual cycles with CD68 and CD163 antibody to measure the expression of panmacrophage and M2 macrophages. Expression of M1 macrophages is the approach of a reduction expression of panmacrophage with M2 macrophages.

Results: Expression of M1, M2 and the ratio M1/M2 in the both of groups had a normal distribution then continued by independent t-test with one-tailed $\alpha(0.05)$. Probability was considered statistically significant at $\mathrm{p}<0.05$ with a confidence interval of $95 \%$. Based on the statistical result, $\mathrm{M} \varphi$ macrophage expression in endometriosis and control group amounted to $3.62 \pm$ 0.50 and $2.80 \pm 0.64(\mathrm{p}=0.0005)$ with non parametric test. The expression of M1 macrophages in endometriosis group and non endometriosis were respectively $1.40 \pm 0.35$ and $1.33 \pm 0.40(\mathrm{p}$ $=0.3005)$ and the expression of M2 in both of group, respectively of $2.23 \pm 0.41$ and $1.47 \pm 0.36(\mathrm{p}=0.0005)$. The ratio of $\mathrm{M} 1 / \mathrm{M} 2$, the endometriosis group and non endometriosis, respectively of $0.65 \pm 0.20$ and $0.92 \pm 0.24(\mathrm{p}=0.0015)$.

Conclusion: this study were significant increased in the panmacrophage M $\varphi$, M2 macrophages expression on a woman's menstrual blood flakes endometriosis and significant decreased in ratio M1/M2 in the woman's menstrual blood flakes endometriosis.
\end{abstract}

Keywords : endometriosis, immunohistochemistry, macrophages M1, M2, menstrual blood.

Correspondence: Yulisa Haslinda, Department of Obstetrics and Gynecology, Faculty of Medicine, Universitas Airlangga, Dr Soetomo Hospital, Surabaya 60286, East Java, Indonesia, Phone: +6281348172277, email: yulisahaslinda@ gmail.com

\section{INTRODUCTION}

Endometriosis is a common gynecological condition that is estimated to occur in $5-15 \%$ of women in reproductive age. Endometriosis is difficult to be detected by doctors and common people. Endometriosis diagnosis is a major obstacle in the management of this disease. Approximately $65 \%$ of this disease has been misdiagnosed with other diseases with an average of delay in diagnosis for \pm 6.8 years. As a result of this delay, the average annual expenditure for endometriosis is very big in every woman.$^{1-3}$
Until now, the gold standard for the diagnosis of endometriosis is laparoscopy. This examination is still quite expensive for most people in Indonesia. In addition, it is also an invasive type of examination. This results many studies focusing to find the right, inexpensive and non-invasive examination that can be used to support the diagnosis of endometriosis. One procedure that is expected to be done to support the diagnosis of endometriosis is by menstruation blood test. ${ }^{4}$

The most widely accepted theory at this point is the retrograde menstruation and implantation theory 
proposed by Sampson in 1920. Some studies suggest that the pathogenesis of endometriosis involves not only retrograde menstruation but also other factors at molecular level as the immune system. A type of immune cells estimated to play an important role in the pathogenesis of endometriosis is macrophage. Capo-bianco in his article mentioned endometriosis as "A disease of macrophage" . 4-6

Generally, there are two phenotypes of macrophages namely macrophages M1 and M2. M1 macrophage is a response of Th, 1 which functions to kill pathogens and stimulate the formation of pro-inflammatory cytokines, while M2 macrophage is in accordance with the Th2 response and serves as a pro-angiogenesis, repairs and forms chronic inflammation-related tissue. ${ }^{7}$ Recently, studies of M1 M2 macrophages in various are widely done. The M1/M2 ratio is predicted to be associated with pregnancy, inflammation, metabolic and cardiovascular disease and cancer. ${ }^{8-9}$ In endometriosis, there is an increased activity of macrophages. Previous research has shown an increase of macrophages in endometriosis tissue. The study by Tran (2009) showed an increase of macrophages in the peritoneal fluid of patients with endometriosis. ${ }^{10}$ Khan (2004) and Berbic et al (2009) found a significant increase of macrophages in eutopic endometrium endometriosis compared with normal endometrium. $^{11-12}$

Menstrual blood is a physiologic blood and endometrium discharge through the vaginaof an unpregnant uterus, under the control of hormones and is repeated periodically during the reproductive period. All thi time, menstrual blood is discarded and is rarely utilized in gynecological field's examination, whereas some previous studies have found that the mononuclear cells composition in menstrual blood is similar to the composition of the eutopik endometrium. ${ }^{13-14}$ The presence of functional endometrium that decay during menstruation, results prediction about macrophages increasement in endometriosis woman's menstrual blood flakes that can improve the expression of M1 and M2 in women with endometriosis. This research on menstrual blood is expected to help explaining the pathogenesis process of endometriosis and finding biomarkers as this disease diagnosing procedure and monitoring.

\section{MATERIALS AND METHODS}

This study design was cross sectional observational analytic. The samples were taken from Endocrine and Reproductive Fertility Clinic in Gynecology Division of Dr. Soetomo Hospital and the immunohistochemical examination was done in Anatomical Pathology Division of Dr. Soetomo Hospital/Faculty of Medicine,
Universitas Airlangga. The study was conducted starting from March 2016 to May 2016. The subjects were women with endometriosis, and as a control, women without endometriosis, with consecutive sampling to pick out 15 people in each group who meet the inclusion and exclusion criteria. The inclusion criteria of the study subjects were women in reproductive age (20-45 years old), women with endometriosis and without endome-triosis, regular menstrual cycles of 28 days \pm 5 days and are willing to sign informed consent to participate in this research. Exclusion criteria were pelvic inflam-matory disease (rectal temperature $>38^{\circ} \mathrm{C}$, vaginal discharge), taking anti-inflammatory or steroids medica-tion in the last 3 days, taking hormonal medication in the last 3 months, IUD acceptor, obesity, gynecology organ malignancy and not representative preparations for histopathological examination. To meet the ethical clearance, priorly this research has received approval from the ethics committee for basic/ clinical research at the Dr. Soetomo Hospital/Faculty of Medicine, Universitas Airlangga, Surabaya.

Tools and materials of this study include information to consent form, speculum, sterile swab, $10 \%$ buffered formalin, tissue prossesing kit, Hematoxylin Eosin examination kit, CD68 antibody immunohistochemistry examination kits, CD163 antibody immunohistochemistry examination kits, light microscope and counting chamber.

The procedure is done by determining the subject of research studies that meet the inclusion and exclusion criteria. The research subjects were asked to come in the second or third day of the next menstrual phases for flake menstrual blood sample collection. Patients were placed in the lithotomy position and a speculum was inserted. Identification of menstrual blood fragments around fornix was performed. Menstrual blood flakes around fornix were taken with minimal volume of $0,5 \mathrm{cc}$. Samples were then fixed in $10 \%$ buffered formalin for 24 hours. Menstrual blood flakes sample were then centrifuged at a speed of $1,500 \mathrm{rpm}$ for 30 minutes to obtain the pellet and supernatant. The pellet was taken as a specimen and paraffin sides were made and stained with hematoxylin eosin. This process was continnued by performing immunohistochemical with labeled Streptavidin Biotin II (LSAB II) methods with CD68 antibody kit (Monoclonal Purified Anti -human CD68 333 801, Biolegend USA) with a 1: 100 dilution and CD163 antibody kit (Purified Monoclonal Anti-human CD163 326 502, Biolegend USA) with a 1: 100 dilution according to the procedure from the Department of Anatomical Pathology Faculty of Medicine, Universitas Airlangga. Expression of M1 macrophages is the approach of a reduction in the expression of panmacrophage M $\varphi$ with M2 macrophages. Data analysis was 
done using independent t-test with a one-tailed $\alpha$ of 0.05 . Probability is considered statistically significant at $\mathrm{p}<0.05$ with a confidence interval of $95 \%$.

\section{RESULTS AND DISCUSSION}

During the study period, we have collected 52 sample of menstrual blood flakes. From 52 samples, only 30 which macrophage cells could be idenified and they were divided into groups of endometriosis samples, amounted 15 samples, and non endometriosis group, amounted 15 samples. In the endometriosis group, found out that, approximately $53.3 \%$ was unilateral endometrioma, $26.7 \%$ was adenomyosis, $12.3 \%$ was combined endometrioma and adenomyosis and 6.7\% was bilateral endometrioma.

Table 1. Characteristics of research subjects

\begin{tabular}{lccc}
\hline \multicolumn{1}{c}{ Characteristics } & Endometriosis & Control & P value \\
\hline Age $($ years $)$ & $34.33 \pm 3.94$ & $33.73 \pm 3.13$ & 0.648 \\
BMI $\left(\mathrm{kg} / \mathrm{m}^{2}\right)$ & $22.57 \pm 2.46$ & $23.28 \pm 3.38$ & 0.516 \\
Number of parity & $0(0-2)$ & $0(0-1)$ & 0.806 \\
Menstrual cycle & $29(25-30)$ & $30(25-31)$ & 0.161 \\
Menstrual duration & $7.00 \pm 1.41$ & $6.53 \pm 1.46$ & 0.381 \\
Dismenorea & & & \\
$\quad$-Yes & $14(93.3)$ & $6(40)$ & 0.007 \\
$\quad$-No & $1(6.7)$ & $9(60)$ & \\
Infertility & $13(86.7)$ & $12(80)$ & 0.623 \\
$\quad$-Yes & $2(16.7)$ & $3(20)$ & \\
-No & & & \\
\hline
\end{tabular}

In both groups of the study sample, found out that patient age, BMI (Body Mass Index), the number of parity, menstrual cycle, duration of menstruation and infertility were homogeneous except the dysmenorrhoea event.

From figures 1 and 2, M $\varphi$ and $\mathrm{M} 2$ macrophages can be seen in menstrual blood flakes characterized by golden color with various cell density. Counting of $\mathrm{M} \varphi$ and $\mathrm{M} 2$ macrophages number was done using counting chamber and Olympus U-B130-2 light microscope (Olympus, Japan). The counting of $\mathrm{M} \varphi$ macrophages' amount on each slide was done at 10 random visual field at a magnification of 400 times in units of cells/mm2.

In this study, the data of $\mathrm{M} \varphi, \mathrm{M} 1$, and $\mathrm{M} 2$ expression and the M1/M2 ratio obtained from each group were tested for normality by using Shapiro-Wilk. Found out that data of M1, M2 expression and the M1/M2 ratio has a normal distribution and qualifies parametric data different test by Independent t-test with a one-tailed $\alpha$ of 0.05 . Probability is considered statistically significant at $\mathrm{p}<0.05$ with a confidence interval of $95 \%$. Nonetheless, we did different tests for $\mathrm{M} \varphi$ macrophage using the Mann-Whitney nonparametric data test with 95\% confidence level and a one-tailed $\alpha$ of 0.05 .

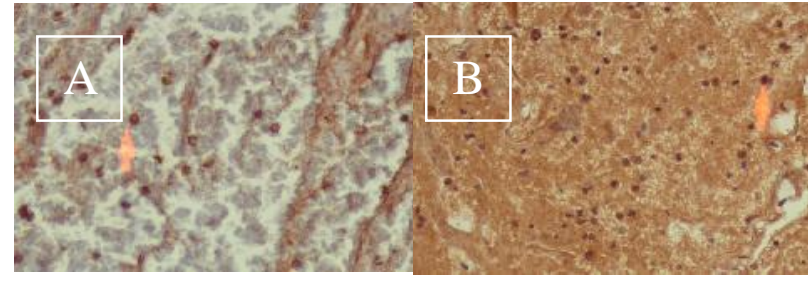

Fig. 1. The results of immunohistochemical staining $\mathrm{M} \varphi$ on endometriosis and non endometriosis woman's menstrual blood flakes (400x magnification; Olympus U-B130-2 Microscope Japan): A. Non Endometriosis, B. Endometriosis

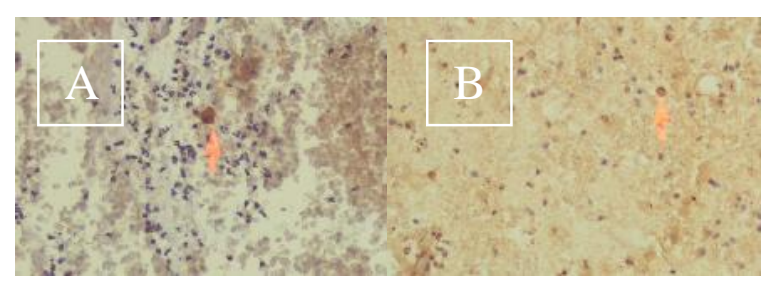

Fig. 2. The results of immunohistochemical staining M2 on endometriosis and non endometriosis woman's menstrual blood flakes (400x magnification; Olympus U-B130-2 Microscope Japan): A. Non Endometriosis, B. Endometriosis

Table 2. Comparison of Macrophage M $\varphi, M 1, \mathrm{M} 2$ expression and the M1/M2 ratio in patients with and without endometriosis

\begin{tabular}{lccc}
\hline \multicolumn{1}{c}{ Characteristics } & Endometriosis & Control & $\mathrm{P}$ \\
\hline M $\varphi$ Macrophage & $3.5(3.1-4.9)$ & $2.7(1.7-4.1)$ & 0.0005 \\
M1 Macrophage & $1.40 \pm 0.35$ & $1.33 \pm 0.40$ & 0.3005 \\
(M $\varphi-\mathrm{M} 2)$ & & & \\
M2 Macrophage & $2.23+0.41$ & $1.47 \pm 0.36$ & 0.0005 \\
M1/M2 Ratio & $0.65 \pm 0.20$ & $0.92 \pm 0.24$ & 0.0015 \\
\hline
\end{tabular}

\section{Panmacrophage M $\varphi$ Expression}

Based on the statistical test, the median, minimum and maximum result of $\mathrm{M} \varphi$ expression are consecutively 3.5; 3.1 and 4.9 in the endometriosis group and those numbers were higher compared to control group which result were 2.7; 1.7 and 4.1. Non-parametric statistical calculations in this study use 0.05 significance level (confident interval of 95\%). This research results $\mathrm{p}=$ 0.0005 and therefore showed significant increase. These results show that in women with endometriosis, occurs physiological changes that disrupt ectopic endometrium homeostatic mechanism and increase macrophage's composition in endometriosis woman's menstrual blood flakes. 
Macrophages living on the tissue or a newly recruited one are a major source of chemokines in tissues that suffered from injury, and as the next additional macrophage recruitment. Macrophages follow neutrophils into sites of inflammation, phagocyte cellular debris and foreign material, and finally out from inflammation sites. The presence of many mononuclear macrophages for long periods on a tissue repairing site $\mathrm{s}$ an indication of chronic inflammation. Macrophage is one of the mononuclear phagocyte, widely distributed in various tissues including the ectopic endometrial tissue, eutopic endometrium and menstrual blood. These results support the previous research done by Molen (2013) where Molen found that menstrual blood mononuclear cells are not similar with mononuclear composition on endometrial biopsy. ${ }^{4,14}$

\section{Macrophage Expression}

From Table 2 it is known that the expression of M1 in endometriosis group and non endometriosis group are respectively $1.40 \pm 0.35$ and $1.33 \pm 0.40$. Statistical calculation in this study uses a 0.05 significance level (confident interval 95\%). This study obtained $\mathrm{p}=0.3005$ showing there is no significant increase between endometriosis group and the control group.

In eutopic endometrium, M1 macrophages have proinflammatory and bactericide characters as a response to IFN- $\gamma$ and LPS. From the results of the exploration deduction and extrapolation of various other studies, we suspect some factors that may result insignificant increase of M1 macrophages' expression in endometriosis group compared with non endometriosis. This unsignificant difference between the two groups showed that in both groups, there was no homeostasis disorders that lead to microbial increased or other sources that possibly trigger the activation of M1 macrophages in eutopic endometrium.

Activation of macrophages to be M1 macrophages phenotypes reflects the acute inflammatory conditions, while the study subjects were patients with endometrioma to severe adenomyosis which process are chronic. This may also affect the results of the research that found no significant increase in the expression of M1 in both groups. Our results are similar with research done by Lagana (2013) which reported that TNF- $\alpha$ levels are very high in the early stages of endometriosis and decrease in accordance with the severity of the disease.15 Research done by Silva (2014), which measured TNF- $\alpha$, one of the mediators that are released in large quantities by M1macrophages using menstrual blood sample and found no significant improvement in the levels of TNF- $\alpha$ on endometriosis and non-endometriosis woman's menstrual and non-endometriosis, but found significant improvement in menstrual blood's levels of TNF- $\alpha$ compared with peripheral blood. This reflects the local inflammatory process that occurs in women with endometriosis. ${ }^{4}$

\section{M2 Macrophages Expression}

Based on the statistical result, there is increase of M2 expression in endometriosis group $(2.23 \pm 0.41)$ compared to the control group $(1.47 \pm 0.36)$ (table 5.3). Statistical calculation in this study used a 0.05 significance level (confident interval 95\%). This study obtained $\mathrm{p}=0.05$ showing there is significant increase of M2 macrophage between endometriosis group and the control group. These results are consistent with studies done by Kumari (2012) which found out that there is an increased expression of M2 macrophages in the endometrial tissue of endometriosis. M2 macrophages have many roles in the pathogenesis of endometriosis. M2 macrophages secrete cytokines and growth factors that contribute to the development and persistence of endometriosis. ${ }^{16}$

Zhang (2015) reported a positive correlation between serum E2 levels and MIF expression in the endometrium of women with endometriosis. This study showed a significant increase in the expression of MIF in endometrial tissue of women with endometriosis and MIF expression in the endometrium of patients with endometriosis that showed increased sensitivity to E2 stimulation. Estrogen can prevent an increase of LPS and IFN- $\gamma$ via M2 macrophages downregulation, resulting in M2 macrophages' activation and decreased M1macrophage. Other studies that support this research is a study conducted Lagana (2013) which reported a local increase of MCP-1 in accordance with the severity levels of the endometriosis disease. ${ }^{17}$

\section{MI/M2 Ratio}

From the statistical tests results, a lower ratio of M1/M2 $(0.65 \pm 0.20)$ was shown in endometriosis group, compared to the control group $(0.92 \pm 0.24)$. Statistical data in this study used a 0.05 significance level (confident interval of 95\%). The results showed $\mathrm{p}=$ 0.0015 , which means that the M1/M2 ratio of women with endometriosis is lower than the control group. The imbalance of M1 and M2 macrophage polarization was associated with various diseases. Several studies have reported that the ratio of M1/M2 was associated with inflammatory process. Increasing ratio of M1/M2 was associated with a polarization of macrophages activation, especially M1 macrophages under acute inflamematory conditions. The decline in M1/M2 ratio was correlated to the domination of M2 macrophages associated with chronic inflammation process. ${ }^{7,20}$ 
Zhang reported that an increase in M1/M2 ratio was found in postmenopausal women, which could be minimalized by estrogen administration. Endometriosis is an estroge-dependent disease, hence, the prevalence of endometriosis in postmenopausal women is minimal. ${ }^{8}$ This can support the idea that the decreasing ratio of M1/M2 was influenced by estrogen level of women with endometriosis. A similar trend was reported by Lagana (2013) where M2 macrophage activation occurred in endometriosis which could stimulate anti inflammatory cytokine production and inhibits the production of proinflamation cytokine's production. ${ }^{15} \mathrm{In}$ endometriosis, a local inflammatory process occurs and triggers an imbalance ratio of M1/M2. The declining of this ratio showed a predominance of M2 macrophages compared to M1 macrophages in women with endometriosis. M2 macrophages play a bigger role in the pathogenesis of endometriosis compared to M1 macrophages. This may be caused by genetic, hormonal, and environmental factors. Estrogen can increase the activity of M2 macrophages via estrogen receptors expressed on the surface. 7,18

In non endometriosis group, the mean of M1/M2 ratio was $0.92 \pm 0.24$. The mean of $\mathrm{M} 1 / \mathrm{M} 2$ ratio which was lower than 1 shows that in the control group, M2 macrophage is more dominant than M1 macrophage. This is in accordance with previous research done by Jensen (2012), which used endometrial tissue taken by hysterectomy procedure towards uterus with non endometrial gynecological abnormalities, and showed that most of the macrophage population of the human endometrium are M2 macrophages.19 Control group characteristics that cannot be separated from other pathological gynecology disorders are also likely to result an imbalance of the M1/M2 ratio.

Endometriosis is a complex disease, whose etiology is not fully understood. The results of this study support the relationship between changes in the composition of menstrual blood and endometriosis incidence. However, it remains unclear whether the alteration of the immune system in endometriosis woman's menstrual blood is primary or secondary to the development of endometriosis itself. The widely various results of other studies about macrophages' density in eutopic endometrium of women with and without endometriosis, are likely to be caused by other external factors, the characteristics of the population and type of endometriosis lesions, instead of the presence or absence of endometriosis. $^{11-12}$

From some literatures that we found, until now there has been no specific immunohistochemical markers of M1 macrophages. Several previous studies used different antibodies to identify M1 macrophages' phenotype, including CD86, CD80 and MHC-II and cytokines from M1 macrophages products which is TNF- $\alpha$. Limitation of our study is that we identified M1 macrophage by reducing from $\mathrm{M} \varphi$ and $\mathrm{M} 2$ macrophages instead of directly identify the M1 macrophages by using specific antibody kit.

The challenge of this research is to obtain representative specimens during the menstrual cycle phase to be performed a comparative analysis. The obstacle in menstrual blood sampling of this study the unwillingness of some Indonesian women to follow this study, considering that menstrual blood is something that is dirty.

Immunological analyzes of the menstrual blood can be suggested as a specimen examination because of the specific immunological nature of menstrual blood, which is different from the peripheral blood and therefore can be very informative in assessing female reproductive organs' health and can be easily obtained through a non-invasive test.

\section{CONCLUSION}

There is a significant increase in the expression of $\mathrm{M} \varphi$ panmacrophages and M2 macrophages in the menstrual blood flakes of women with endometriosis compared to women without endometriosis. There is a significant decrease in the M1/M2 ratio of the menstrual blood flakes of women with endometriosis compared to women without endometriosis

\section{REFERENCES}

1. Samsulhadi. Endometriosis: Dari biomolekuler sampai masalah klinis. Majalah Obstetri dan Ginekologi. 2002;10:43-50.

2. Arruda MS, Petta CA, Abrao MS and Benetti Pinto CL. Time elapsed from onset of symptoms to diagnosis of endometriosis in a cohort study of Brazilian women. Human Reproduction. 2003;18(4):756-9.

3. Hendarto H. Endometriosis dari Aspek Teori sampai Penanganan Klinis. Patogenesis. Surabaya: Airlangga University Press; 2015. hal. 9-22.

4. Da Silva CM, Belo AV, Andrade SP, Campos PP, Ferreira MCF, Da Silva-Filho AL and Carneiro MM. Identification of local angiogenic and inflammatory markers in the menstrual blood of women with endometriosis. Biomedicine \& Pharmacotherapy. 2014;68(7):899-904. 
5. Capobianco, Annalisa and Patrizia Rovere-Querini. Endometriosis, a disease of the macrophage. Front Immunol, 2013;4(9).

6. Sourial S, Tempest $\mathrm{N}$ and Hapangama D. K. Theories on the pathogenesis of endometriosis. International journal of reproductive medicine. 2014.

7. Wang XQ, Yu J, Luo XZ, Shi YL, Wang Y, Wang $\mathrm{L}, \mathrm{Li}$ DJ. The high level of RANTES in the ectopic milieu recruits macrophages and induces their tolerance in progression of endometriosis. J Mol Endocrinol. 2010;45:291-9.

8. Wang $\mathrm{N}$, Liang $\mathrm{H}$ and Zen $\mathrm{K}$. Molecular mechanisms that influence the macrophage M1-M2 polarization balance. M1/M2 Macrophages: The Arginine Fork in the Road to Health and Disease. 2015;230.

9. Brown MB, von Chamier M, Allam AB and Reyes L. M1/M2 macrophage polarity in normal and complicated pregnancy. M1/M2 Macrophages: The Arginine Fork in the Road to Health and Disease. 2015:205.

10. Tran LVP, Tokushige N, Berbic M, Markham R and Fraser IS. Macrophages and nerve fibres in peritoneal endometriosis. Human reproduction. 2009

11. Khan KN, Masuzaki H, Fujishita A, Kitajima M, Sekine I and Ishimaru T. Differential macrophage infiltration in early and advanced endometriosis and adjacent peritoneum. Fertility and sterility. 2004;81(3):652-61.

12. Berbic M, Schulke L, Markham R, Tokushige N, Russell $\mathrm{P}$ and Fraser IS. Macrophage expression in endometrium of women with and without endometriosis. Human reproduction. 2009;24(2) :325-32.

13. Takahashi K, Nagata $\mathrm{H}$ and Kitao M. Clinical usefulness of determination of estradiol level in the menstrual blood for patients with endometriosis.
Nihon Sanka Fujinka Gakkai Zasshi. 1989;41(11):1849-50.

14. Molen Van Der RG, Schutten JHF, van Cranenbroek B, Ter Meer M, Donckers J, Scholten RR and Joosten I. Menstrual blood closely resembles the uterine immune micro-environment and is clearly distinct from peripheral blood. Human Reproduction. 2013:398.

15. Lagana SA, Emanuele S, Giovanni R, Vincenza S and Onofrio T. Interplay between Misplaced Müllerian-Derived Stem Cells and Peritoneal Immune Dysregulation in the Pathogenesis of Endometriosis. Obstetrics and Gynecology International. 2013.

16. Kumari SA, Pearson CB, Hachey AM, Xia DL and Wachtman LM. Alternative activation of macrophages in rhesus macaques (Macaca mulatta) with endometriosis. Comparative medicine. 2012;62(4):303-10.

17. Zhang, Xiao and Lin Mu. Association between macrophage migration inhibitory factor in the endometrium and estrogen in endometriosis. Experimental and therapeutic medicine. 2015;10(2):787-91.

18. Toniolo A, Fadini GP, Tedesco S, Cappellari R, Vegeto E, Maggi A and Cignarella A. Alternative activation of human macrophages is rescued by estrogen treatment in vitro and impaired by menopausal status. The Journal of Clinical Endocrinology \& Metabolism. 2014;100(1):50-8.

19. Jensen AL, Collins J, Shipman EP, Wira CR, Guyre PM and Pioli PA. A subset of human uterine endometrial macrophages is alternatively activated. American Journal of Reproductive Immunology. 2012;68(5):374-86.

20. Zhang M, He Y, Sun X, Li Q, Wang W, Zhao A and Di W. A high M1/M2 ratio of tumor-associated macrophages is associated with extended survival in ovarian cancer patients. Journal of ovarian research. 2014;7(1):1. 